\title{
Potential Suitable Habitat Distribution and Conservation Strategy for the Siberian Crane (Grus leucogeranus) at Spring Stopover Sites in Northeastern China
}

\author{
Ding Wen ${ }^{1,2}$, Yuanman Hu${ }^{1 *}$, Zaiping Xiong1, Yu Chang', Yuehui Li ${ }^{1}$, \\ Yong Wang ${ }^{3}$, Miao Liu' ${ }^{1}$, Jinghai Zhu ${ }^{1,4}$ \\ ${ }^{1}$ CAS Key Laboratory of Forest Ecology and Management, Institute of Applied Ecology, \\ Chinese Academy of Sciences, Shenyang, China \\ ${ }^{2}$ University of Chinese Academy of Sciences, Beijing, China \\ ${ }^{3}$ Momoge Nature Reserve Bureau, Zhenlai, China \\ ${ }^{4}$ China Medical University, Shenyang, China
}

Received: 14 August 2019

Accepted: 27 October 2019

\begin{abstract}
The wetlands where the migratory waterfowl stop during their migration, also called stopover wetlands, are important nodes where migratory waterfowl supplement their energy and food. The Siberian crane (Grus leucogeranus), a wetland obligate endangered species, is highly dependent on a series of stopovers on the migration route. Although some conservation measures have been adopted in China, it is still necessary to develop an appropriate management strategy to preserve this endangered species at different stopover areas. This paper used maximum entropy modeling to evaluate habitat suitability for the migration of the Siberian crane. We found that vegetation community type and water depth are the most important factors affecting the distribution of the Siberian crane during the migration period. For Siberian crane migration, the most suitable water depth does not exceed $60 \mathrm{~cm}$, the desirable land cover type is swamp, the most suitable community is Phragmites-Sparganium, the most suitable vegetation coverage is from $8 \%$ to $35 \%$, the distance from a residential area is over $2800 \mathrm{~m}$, and the distance from a road is over $2000 \mathrm{~m}$. On this basis, some specific conservation strategies are proposed for better protection and management of the Siberian crane's habitat. These results can serve as a reference point for the preservation and management of the potential habitats of similar endangered waterfowl.
\end{abstract}

Keywords: wetland, Siberian crane (Grus leucogeranus), habitat, conservation strategy, stopover

*e-mail: huym@iae.ac.cn 


\section{Introduction}

Wetlands are one of the ecosystems that have the most abundant biodiversity, providing water, food, shelter, breeding sites and habitat for waterfowl [1, 2]. Wetlands that are distributed on the migratory routes of birds are called stopover wetlands. They are important energy and food supply stations for migratory waterfowl and have important ecological significance in maintaining the population quantity and stability of migratory waterfowl species [3]. However, many of the world's wetlands have been degraded or have disappeared due to climate change, water pollution, and human disturbance [4-6]. The degradation and loss of stopover wetlands has a strong impact on the waterfowl population during migration - especially the changes that occur at important international stopover sites [7, 8]. Strict measures should be taken to conserve waterfowl habitat. In addition, habitat suitability assessment is fundamental to conservation planning.

Previous studies of migratory birds were mainly focused on the effects of habitat $[4,9]$ and the selection of breeding areas and wintering grounds [10-13]. Research on the ecological selection of stopover areas is seldom documented [3, 14]. The habitat suitability assessment of the stopover areas of migratory waterfowl may aid in understanding why waterfowl choose certain sites. Species distribution models have become important tools to assess habitat suitability in recent years.

Species distribution models (SDMs) use environmental factors and geographic information to interpret and predict the occurrence probability of species [15]. The MaxEnt (maximum entropy model) developed by Phillips et al. in 2006 is a model that estimates the probability density of the occurrence of species, which is utilized to infer and predict the potential geographical distribution of species [16]. MaxEnt avoids the shortcomings of the subjectivity of mechanism models and the difficulty of obtaining input data of regression models. It is extremely suitable for the evaluation of habitat suitability for rare and endangered species with limited occurrence data [13, 17, 18]. Therefore, MaxEnt has been widely applied to quantify the relationship between species distribution and environmental factors and to predict the potential distribution of species [19]. The model can also be used to evaluate habitat suitability for species, such as in some waterfowl habitat evaluation [13, 20, 21].

The Siberian crane is a wetland obligate waterfowl. It prefers to wade and forage on the tubers of submerged aquatic macrophytes by using its long beak in soft mudflats with water saturation or shallow water. However, in recent years, due to the overexploitation of wetland resources through activities such as reclamation, grazing, and oil drilling, the living habitats of Siberian cranes have been reduced or destroyed [9, $22,23]$. The number of Siberian cranes is continuously decreasing. Therefore, the habitat requirements of
Siberian cranes should be clarified, and suitability of habitat for the species should be assessed to make scientific decisions to better preserve the valuable species. In this paper, we use the MaxEnt model to understand the Siberian crane's distribution and habitat selection and to guide future conservation efforts. Our objectives were to: (1) explore how the Siberian crane responds to different environmental determinants during spring migration, (2) determine the spatial distribution of potentially suitable habitats for the crane, and (3) provide suggestions for local wetland managers to effectively protect crane habitat.

\section{Materials and Methods}

\section{Study Area}

Momoge National Nature Reserve (MNNR) is located at N $45^{\circ} 42^{\prime} 25^{\prime \prime}-46^{\circ} 18^{\prime} 0^{\prime \prime}$, E $123^{\circ} 27^{\prime} 0^{\prime \prime} \sim 124^{\circ} 4^{\prime} 33^{\prime \prime}$ in the western Songnen Plain in Jilin Province, China (Fig. 1). It covers an area of $1440 \mathrm{~km}^{2}$. The average elevation is approximately $142 \mathrm{~m}$ above sea level. MNNR is the most important stopover area along the East Asian-Australasian Flyway in northeastern China, attracting approximately $95 \%$ of all Siberian cranes globally to replenish their energy from April to May each year $[9,24]$. According to the satellite tracking results, the MNNR is a long-term refueling stopover site during the Siberian crane migration $[24,25]$ due to its abundant wetland types and numerous lakes and rivers. MNNR is a Ramsar site and was founded in 1981 with the major purpose of protecting endangered waterfowl, such as Grus leucogeranus, Grus japonensis, Grus grus, Oriental white stork and Grus monacha.

The study area belongs to the continental temperate monsoon climate zone and is characterized by an average annual temperature of $4.9^{\circ} \mathrm{C}$ and average annual precipitation of approximately $400 \mathrm{~mm}$. Four rivers (the Nen, Tao'er, Erlongtao and Huerda) flow through Momoge Reserve. Due to drought and reservoir construction, only the Nen and the Tao'er flow into the MNNR. Eighty percent of the MNNR is composed of inland salt marshes [26].

\section{Observation of the Occurrence of Siberian Cranes}

During April and May 2018, we used a monocular telescope (Nikon MONARCH 82ED-A) to observe the cranes along with MNNR administration staff. The staff has considerable fieldwork experience and knows where to find the cranes. In combination with the MNNR administration staff's daily monitoring routes and points, we used fixed-point observation and line transect sampling methods to determine 20 sites where Siberian cranes occur during spring migration (Fig. 1). Because we were unable to reach the Siberian cranes, the occurrence sites were estimated based on the 


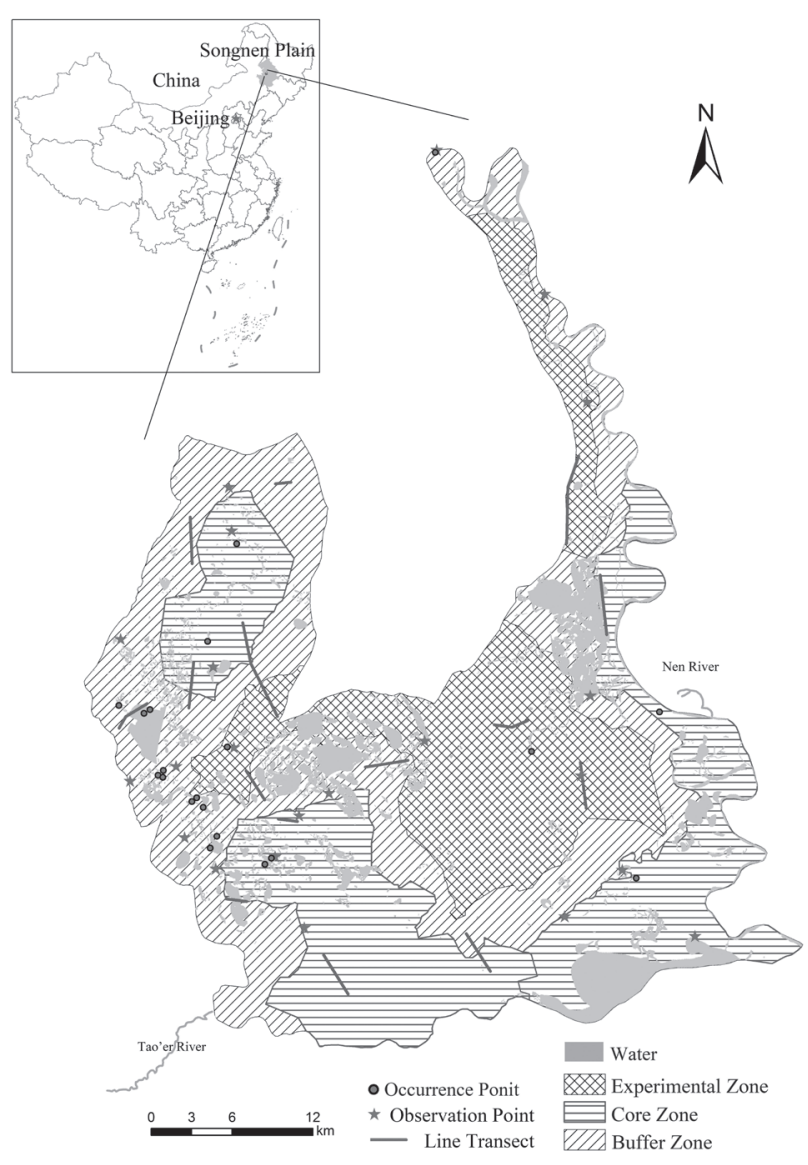

Fig. 1. Locations of the MNNR and occurrence points of Siberian cranes.

directions and distances between the observing locations and the rangefinder telescope. The coordinates of these points were sorted into Excel tables and imported into ArcGIS 10.3 and then converted into the ASCII format required by the MaxEnt software.

\section{Environmental Variables}

Previous studies have shown that land cover, human disturbances, vegetation coverage, vegetation communities and water depth are the key factors affecting the habitat requirements of Siberian cranes in Momoge wetlands [9, 22, 27]. No bioclimatic predictors were used because these datasets were usually coarsely scaled and more suited to regional or continental SDMs. We also sampled 126 sites across the MNNR through a field survey. The geographical coordinates, vegetation cover, vegetation types, and average water depth at each sampling site were recorded using a handheld GPS. The sampling sites were spatially scattered to avoid autocorrelation issues.

\section{Land Cover}

We generated a land cover map by classifying remotely sensed data. Landsat 8 OLI image (WRS-2 path 120 row 28) from May 21, 2018, was acquired from the U.S. Geological Survey website (http://glovis. usgs. gov/). Before the image was classified by land cover type, $1: 100,000$ topographic maps were used to correct the image, and the root mean squared error was controlled within 0.5 pixels. Furthermore, the GF-2 images obtained from the China Center for Resource Satellite Data and Application (http://218.247.138.119:7777/ DSSPlatform/productSearch.html) were used as supplemental data. The land cover was divided through visual interpretation into 7 types: 1-swamp, 2-cultivated land, 3-residential area, 4-woodland, 5-water body, 6-saline-alkali land and 7-grassland. The accuracy of the visual image classification was evaluated at 126 field sampling points, and the accuracy was $89.6 \%$.

\section{Human Disturbances}

Human disturbances included distance to road and distance to residential areas. The roads were obtained from Google Earth and GF-2 images by visual interpretation. The residential areas were extracted from the Momoge Wetland land cover map. The Euclidean distances to roads and residential areas were calculated using the Spatial Analyst toolbox in ArcGIS 10.3.

\section{Vegetation Coverage}

This paper estimates the vegetation coverage of MNNR based on the NDVI method for dimidiate pixel model [28]. The NDVI value was derived from the Landsat 8 OLI image and was calculated in Envi 5.3 software.

\section{Vegetation Communities}

The original vegetation community map was provided by the MNNR administration, and then we updated the map with remote sensing images and field survey data. Vegetation community types are divided into 12 types: 1-Phragmites communisScirpus yagara community, 2-paddy field, 3-dry land, 4-Carex-Calamagrostis angustifolia community, 5-Phragmites communis-Typha angustifolia community, 6-Typha angustifolia-Calamagrostis angustifolia community, 7-woodland, 8-Leymus chinensis-Suaeda glauca community, 9-Leymus chinensis community, 10-Phragmites communis-Leymus chinensis community, 11-Leymus chinensis-weeds community, and 12-water body.

\section{Water Depth}

The modified normalized difference water index (MNDWI) was used to extract the water surface, and the DEM data and field survey data were used to divide the water area into water depths. DEM is the abbreviation of Digital Elevation Model. It is in raster format with each cell value representing the elevation (m) a.s.l. The data was acquired from the 
U.S. Geological Survey website (http://glovis. usgs. gov/). The Siberian crane prefer shallow water ranging from 0 to $60 \mathrm{~cm}$, and we divided the water depth into 4 consecutive grades: $1: \sim 0 \mathrm{~cm}, 2: 0-30 \mathrm{~cm}, 3: 30-60 \mathrm{~cm}$, and 4: $>60 \mathrm{~cm}$.

To reduce the influence of multiple collinearity on the MaxEnt model, the correlation test of the environmental variables was carried out in $\mathrm{R}$ 3.0.1 (http://www.r-project.org/), and the factors with high correlation $(r>0.8)$ were eliminated. The results showed that the above six environmental factors were all aligned with the requirements. Therefore, the following factors (Fig. 2) were used to build the model: (1) land cover types, (2) distance to residential area, (3) distance to roads, (4) vegetation coverage, (5) vegetation communities and (6) water depth. Finally, using the ArcGIS 10.3 platform, each factor layer was projected into the WGS 84 coordinate system and converted into raster format with a cell size of $30 \mathrm{~m}$.

\section{Model Construction and Verification}

The species occurrence point data and the environmental variable data were imported into the MaxEnt software (3.4.1). Seventy-five percent of the species occurrence data points were randomly selected to establish the model, and the remaining $25 \%$ of points were selected for model validation. The average value of the 15 replicate simulations by subsample run type was taken as the final simulation result. Other parameters were set as follows: "maximum number of background points" was 10,000 , "maximum iterations" was 500 , the "convergence threshold" was set as 0.00001 , and the regularization multiplier was set as 1 .

The importance of environmental factors was analyzed using jackknife analysis, and the model performance accuracy was evaluated by area under the curve (AUC) of the receiver operator characteristic (ROC). The AUC value ranged from 0-1; larger AUC values indicate higher prediction accuracy of the constructed model and better predictions [19].
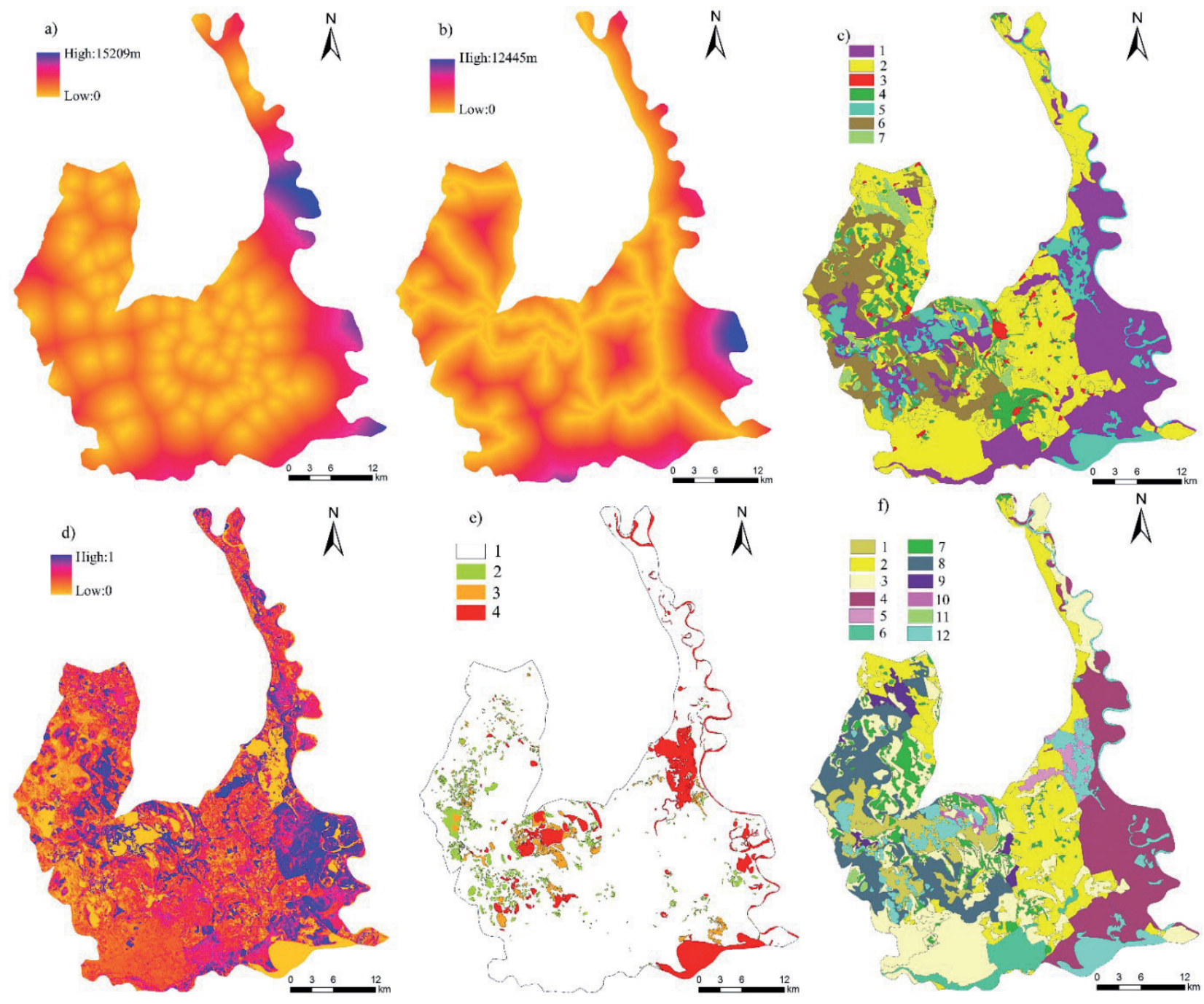

Fig 2. Factors affecting habitat selection of the Siberian crane: a) distance to residential areas, b) distance to roads, c) land cover, d) vegetation coverage, e) water depth, f) vegetation communities. 


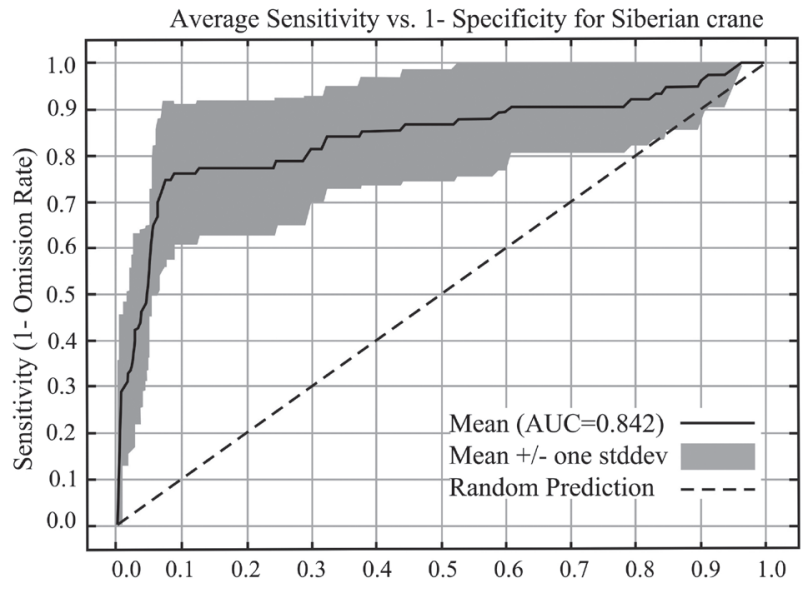

Fig. 3. ROC curve of MaxEnt prediction.

\section{Results and Discussion}

\section{Model Performance}

The ROC curve (Fig. 3) shows that the AUC value is 0.842 , indicating that the simulation results of the MaxEnt model are relatively accurate.

\section{Suitable Siberian Crane Habitats During Spring in MNNR}

To map the potential habitats of the Siberian crane, the maximum test sensitivity and specificity values were applied to determine the cutoff point for the model $[29,30]$. This threshold maximizes the number of cases where the model erroneously assigns unsuitable habitat and misses suitable habitat. Then, we divided the habitat map into suitable ( $\geq$ threshold value) and unsuitable $(<$ threshold value) based on the equal training sensitivity and specificity logistic threshold.

The optimal cutoff value was 0.3258 . The total area of suitable habitat (Fig. 4) for the Siberian crane during spring in MNNR was $87.55 \mathrm{~km}^{2}$, of which $37.3 \mathrm{~km}^{2}$ (or $42.6 \%$ of the total area) was in the core zone; $41.36 \mathrm{~km}^{2}$ (47.24\%) was in the buffer zone; and $8.89 \mathrm{~km}^{2}$ (10.15\%) was in the experimental zone.

\section{The Relationship Between Habitat Suitability and Environmental Factors}

The Jackknife analysis of the model tested the contribution of each potential environmental variable to the spring migration habitat distribution of the Siberian crane in the MNNR. As shown in Table 1, the vegetation community, water depth and vegetation coverage were the main factors affecting the distribution of the Siberian crane, accounting for $94.4 \%$ of the total contribution rate.

The Jackknife test also showed (Fig. 5) that the vegetation community and the water depth have a greater impact on the prediction results; that is, the distribution probability of the Siberian crane is more sensitive to these factors.

The response curve of environmental variables to predicted probability contribution is shown in Fig. 6 . The results showed that the most suitable water depths for the Siberian crane were between $0-30 \mathrm{~cm}$ and that 30-60 $\mathrm{cm}$ was also an appropriate depth. The probability of occurrence at 0-30 cm water depth exceeds 0.8 and goes down to 0.7 at a relatively deep water depth.
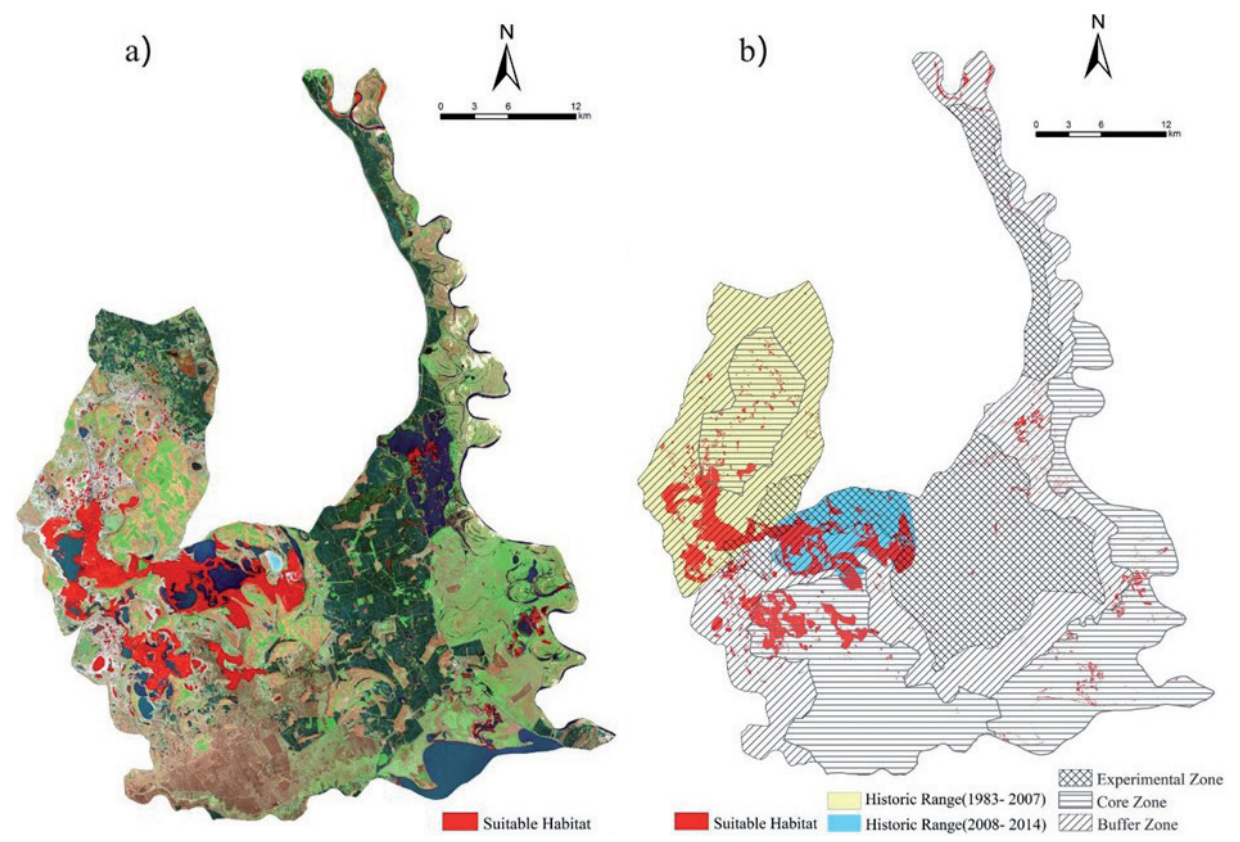

Fig. 4. Potential habitats map of the Siberian crane: a) Landsat 8 image overlap map (R-7 G-5 B-3, time: 2018.5.21); b) historic range overlap map. 
Table 1. The contribution rate of environmental factors.

\begin{tabular}{|c|c|c|}
\hline Environmental variable & Percent contribution(\%) & Permutation importance(\%) \\
\hline Vegetation communities & 46.4 & 30.2 \\
\hline Water depth & 33.9 & 37 \\
\hline Vegetation coverage & 14.1 & 8.2 \\
\hline Land cover types & 3.3 & 0.4 \\
\hline Distance to roads & 1.4 & 4.9 \\
\hline
\end{tabular}

Within 2800 meters of the settlement points, the probability of occurrence increased rapidly with increasing distance, rapidly increasing from 0.3 to 0.6 and reaching a peak at $2800 \mathrm{~m}$; the probability then declined rapidly with increasing distance. When the distance reached $6000 \mathrm{~m}$, the probability was only 0.38 . Within 500 meters of the roads, the probability of occurrence increased rapidly with increasing distance, increasing rapidly from 0.37 to 0.52 , and reaching a peak of 0.52 at $2000 \mathrm{~m}$, and then decreasing with increasing distance, reaching only 0.42 at $6000 \mathrm{~m}$.

The most suitable vegetation coverage for the Siberian crane was $8-35 \%$. When vegetation coverage ranged from 0 to $8 \%$, the probability of Siberian crane presence increased significantly, reaching a maximum of 0.68 , and then slowly decreased to 0.65 when the vegetation coverage reached $15 \%$. The probability quickly dropped to 0.45 with the vegetation coverage increasing to $35 \%$.

The most suitable community for the Siberian crane is the Phragmites communis-Scirpus yagara community, and swamp wetlands are the largest available type.

\section{Spatial Distribution of the Potential Habitats of the Siberian Crane}

The habitat suitability distribution map (Fig. 4) shows that the potential habitats of the crane are mainly distributed in the central and western parts of the reserve. The majority are located in the core zone and buffer zone of the MNNR, and very few are located in the experimental zone.

The Siberian crane is a large waterfowl and is very sensitive to environmental changes, such as changes in hydrological conditions and the stopover site [31]. In recent years, due to human factors and global climate change, the landscape pattern of the MNNR has undergone serious changes [32]. Due to the population increase and the reclamation of wetlands for farmland, the Siberian crane lost the appropriate hydrological conditions. The core zone in the northwest of the MNNR has been the main stop for the Siberian crane for the past 10 years [31]. Due to wetland degradation, there are only sporadic areas suitable stopover areas for the Siberian crane, and these habitat patches are fragmented. A drainage area has been built in the western buffer zone of the MNNR and now forms a relatively open water area, which can form suitable hydrological conditions for the Siberian crane. From 2008 to 2014, due to the irrigation and drainage of paddy fields, the buffer zone in the middle of the MNNR maintained a certain water surface area and water level and was the main stopover site for Siberian cranes [9, 23]. In recent years, the water intake in the area has been too large, and the water level is too high as a result of a lack of scientific water management; the area is no longer suitable for a large group of Siberian cranes, and the habitat is fragmented [9]. However, the results in Fig. 4 show that the area is still potential habitat for the Siberian crane. If the water level management can be strengthened, the area may still become a stopover site for the Siberian crane. In contrast, the core zone in the middle of the MNNR, due to the retreat of rice fields and the drainage of reservoirs, can form different sizes of ponds to meet the needs of the Siberian crane. Due to the oilfield production facilities and production activities in the eastern part of the MNNR, suitable habitat for the Siberian crane has almost all been lost.

\section{Environmental Factors Affecting the Distribution of the Siberian Crane}

Water is the most important ecological factor for Siberian cranes and plays an extremely important role in migration, habitat and feeding. The effects of hydrological conditions on wetland waterfowl are direct or indirect [33]. For example, the water level affects the spatial structure of the wetland, the type of vegetation, the availability of food, and the microhabitat of the habitat [34]. The most suitable water depths for the Siberian crane were between 0 and $30 \mathrm{~cm}$, indicating that the Siberian crane prefers shallow water marsh and wet meadows for foraging. Our results are in line with those of previous studies [9, 22, 27, 31, 35]. However, we also found that 30 to $60 \mathrm{~cm}$ is the preferred depth for the Siberian crane during spring, demonstrating that the Siberian crane can feed in relatively deep water where disturbances from humans and livestock are relatively few. In addition, the soil in the deep water area is water-saturated and softer than the water in shallow areas, and the Siberian crane consumes less energy when foraging. 


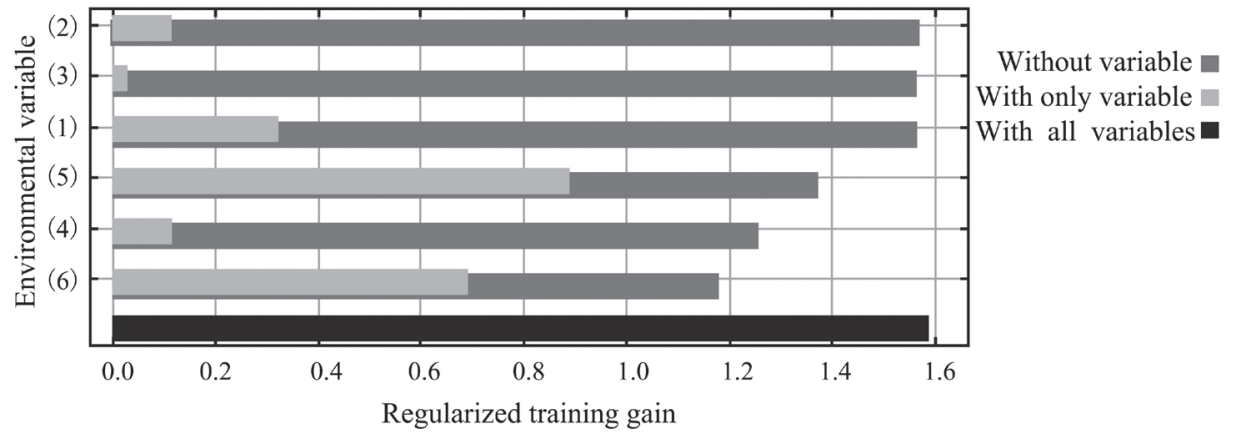

Fig. 5. Jackknife analysis of environmental variables.

The quantity, quality and accessibility of food resources are the decisive factors for whether waterfowl can obtain enough energy and are also the direct cause behind stopover location choice [36]. Our results indicated that the Phragmites communis-Scirpus yagara community was the favorite plant community type for the Siberian crane, which mainly feeds on plants, and the roots and buds are its main food sources. Studies have shown that Scirpusp laniculm is the main source of food [9, 22]. Scirpusp laniculm grows in floodplains, swamps, paddy fields, riverbanks, lakes, and alkaline meadows, which are often associated with the Phragmites communis-Scirpus yagara community. Our results also showed that the most suitable land cover type for the Siberian crane was marsh.

The various human activities in the wetlands are the main disturbances in the migration and habitat of waterfowls $[37,38]$. Strong positive correlations were found between human disturbances and the number of Siberian cranes [12]. The suitable distances to
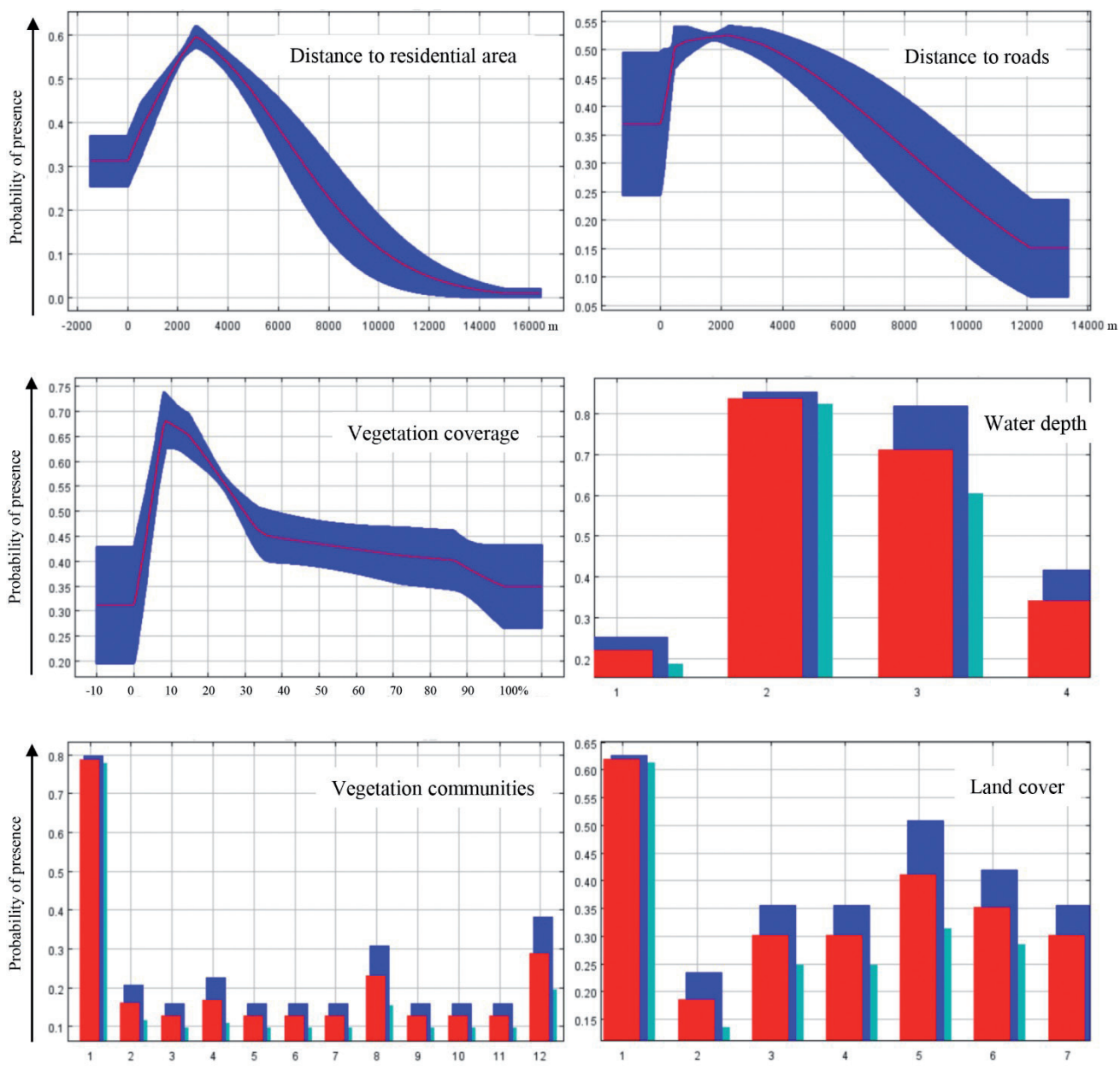

Fig. 6. Response curve of environmental variables to predicted probability contribution: mean of running results in red, standard deviation in blue. 
the residential areas and roads were farther than $2000 \mathrm{~m}$. When the distances to these disturbances exceeded $2500 \mathrm{~m}$, the probability of occurrence of the species tended to decrease gradually. This phenomenon indicated that the maximum impact distance of these human disturbances was $2500 \mathrm{~m}$.

The Siberian crane is naturally alert and prefers to choose open areas with fewer disturbances as its main stopover sites. The optimal vegetation covers for the Siberian cranes were between $8 \%$ and $35 \%$, which was similar to the findings of Kong et al. [27]. When vegetation coverage was over $35 \%$, it was no longer an influential factor for the emergence of the Siberian crane, indicating that sparse vegetation is the preferred habitat for the Siberian crane. Lower vegetation coverage enables the Siberian crane to detect enemies earlier.

\section{Implications for the Conservation of the Siberian Crane}

Momoge Wetland is an internationally important migration stopover for the Siberian crane. Due to the increasing demand for agricultural products, wetlands are facing unprecedented agricultural and commercial development. It is particularly urgent to use and optimize existing wetland patterns to improve migratory waterfowl's habitat. In conjunction with the findings of this paper, the following suggestions are put forward for better protection and management of the habitat of Siberian crane.

\section{Scientific Supplementary Water}

Since the late 1980s, and especially since the 1990s, the local government has built water conservation infrastructure projects such as reservoirs, enclosed lakes and water diversion projects, which have seriously damaged the original hydrological pattern of wetlands. The dryness of the wetlands, which is caused by a lack of water, as well as excessive water saturation, has had a considerable impact on the crane's foraging and perching. Water levels that are too low or too high as well as dramatic changes in water level will directly affect the crane's suitable habitat selection; on the other hand, these will also affect the growth of the crane's food: Scirpus laniculm. Therefore, it is recommended that the MNNR administration make a scientific and rational water replenishment plan to improve hydrological conditions and to establish a long-term water replenishment mechanism for the reserve.

\section{Less Human Interference}

The waterfowl habitat in the MNNR is seriously disturbed by anthropogenic activities such as the building of roads and villages and the cultivation of land in the protected area. Roads in the protected area are staggered, and road construction has brought about rapid economic development, but it has also brought serious threats to the quality of waterfowl habitats in the protected areas. The area of cultivated land in the MNNR has increased year after year. Field investigations have found that wetlands have been reclaimed into farmland in the buffer and core zones. These anthropogenic factors pose a tremendous threat to the Siberian crane. It is recommended that MNNR administration managers strengthen publicity for waterfowl conservation awareness and raise people's awareness of the importance of waterfowl biodiversity conservation.

\section{Conclusions}

In recent years, with global climate change and the increase in human activities, the wetlands on the migratory route have undergone drastic changes. In this paper we used the MaxEnt model, which was driven by the occurrence points of Siberian cranes, to establish the relationship between the stopover wetland's ecological factors and the habitat selection of the Siberian crane to provide theoretical support for the protection of migratory populations of the Siberian crane. At the same time, this paper provides a reference for the restoration and management of large wading bird habitats in other areas of China.

\section{Acknowledgements}

This work was financially supported by the National Key Research and Development Program of China (No. 2016YFC0500401) and the National Natural Science Foundation of China (No. 41871197). We also thank Changlin Zou and Baocai Xu from the Momoge National Nature Reserve for their help with fieldwork.

\section{Conflict of Interest}

The authors declare no conflict of interest.

\section{References}

1. TURNER R.K., VAN DEN BERGH J.C.J.M., SÖDERQVIST T., BARENDREGT A., VAN DER STRAATEN, J., MALTBY E., VAN IERLAND E.C. Ecological-economic analysis of wetlands: scientific integration for management and policy. Ecological Economics, 35, 7-23, 2000.

2. JUNK W.J., BROWN M., CAMPBELL I.C., FINLAYSON M., GOPAL B., RAMBERG L., WARNER B.G. The comparative biodiversity of seven globally important wetlands: a synthesis. Aquatic Sciences, 68, 400, 2006.

3. LEU M., THOMPSON C.W. The potential importance of migratory stopover sites as flight feather molt staging areas: a review for neotropical migrants. Biological Conservation, 106, 45, 2002. 
4. S. BEATTY W., WEBB E., KESLER D., H. RAEDEKE A., NAYLOR L., HUMBURG D. Landscape effects on mallard habitat selection at multiple spatial scales during the non-breeding period. Landscape Ecology, 29, 989, 2014.

5. MA Z., CAI Y., LI, B., CHEN J. Managing Wetland Habitats for Waterbirds: An International Perspective. Wetlands, 30, 15, 2010.

6. LEMOINE N., BAUER H., PEINTINGER M., BÖHNING-GAESE K. Effects of Climate and Land-Use Change on Species Abundance in a Central European Bird Community. Conservation biology: the journal of the Society for Conservation Biology, 21, 495, 2007.

7. SOMVEILlE M., MANICA A., BUTCHART S.H., RODRIGUES A.S. Mapping global diversity patterns for migratory birds. PLoS One, 8, e70907, 2013.

8. HANSEN B., MENKHORST P., MOLONEY P., LOYN $\mathrm{R}$. Long-term declines in multiple waterbird species in a tidal embayment, south-east Australia. Austral Ecology, 40, 2015.

9. JIANG H., WEN Y., ZOU L., WANG Z., HE C., ZOU C. The effects of a wetland restoration project on the Siberian crane (Grus leucogeranus) population and stopover habitat in Momoge National Nature Reserve, China. Ecological Engineering, 96, 170, 2016.

10. JIA Y., JIAO S., ZHANG Y., ZHOU Y., LEI G., LIU G. Diet Shift and Its Impact on Foraging Behavior of Siberian Crane (Grus Leucogeranus) in Poyang Lake. PLoS One, 8 , e65843, 2013.

11. MALEKI S., SOFFIANIAN,A.R., SOLTANI KOUPAEI S., SAATCHI S., POURMANAFI S., SHEIKHOLESLAM F. Habitat mapping as a tool for water birds conservation planning in an arid zone wetland: The case study Hamun wetland. Ecological Engineering, 95, 594, 2016.

12. HUANG Z., LU L., JIAO G., JIANG J., YE Q. Analysis of the correlations between environmental factors and rare cranes in the Poyang Lake region of China. Journal of Great Lakes Research, 44, 140, 2018.

13. NA X., ZHOU H., ZANG S., WU C., LI W., LI M. Maximum Entropy modeling for habitat suitability assessment of Red-crowned crane. Ecological Indicators, 91, 439, 2018.

14. ALBANESE G., DAVIS C. Characteristics within and around stopover wetlands used by migratory shorebirds: Is the neighborhood important? The Condor, 117, 328, 2015.

15. ELITH J., GRAHAM C.H. Do they? How do they? WHY do they? On finding reasons for differing performances of species distribution models. Ecography, 32, 66, 2009.

16. ELITH J., PHILLIPS S.J., HASTIE T., DUDÍK M., CHEE Y.E., YATES C.J. A statistical explanation of MaxEnt for ecologists. Diversity and Distributions, 17, 43, 2011.

17. ZACARIAS D., LOYOLA R. Distribution modelling and multi-scale landscape connectivity highlight important areas for the conservation of savannah elephants. Biological Conservation, 224, 1, 2018.

18. WU W., LI Y., HU Y. Simulation of potential habitat overlap between red deer (Cervus elaphus) and roe deer (Capreolus capreolus) in northeastern China. PeerJ, 4, e1756, 2016.

19. PHILLIPS S.J., ANDERSON R.P., SCHAPIRE R.E. Maximum entropy modeling of species geographic distributions. Ecological Modelling, 190, 231, 2006.

20. MORENO R., ZAMORA R., MOLINA J.R., VASQUEZ A., HERRERA M.Á. Predictive modeling of microhabitats for endemic birds in South Chilean temperate forests using Maximum entropy (Maxent). Ecological Informatics, 6, 364, 2011.

21. NAOE S., KATAYAMA N., AMANO T., AKASAKA M., YAMAKITA T., UETA M., MATSUBA M., MIYASHITA T. Identifying priority areas for national-level conservation to achieve Aichi Target 11: A case study of using terrestrial birds breeding in Japan. Journal for Nature Conservation, 24, 101, 2015.

22. HE C., SONG Y., LANG H., LI H., SUN X. Migratory dynamics of Siberian crane and environmental conditions at its stop-over site. Chinese Biodiversity, 10, 286, 2002.

23. WANG Y., FENG J., LIN Q., LYU X., WANG X., WANG G. Effects of crude oil contamination on soil physical and chemical properties in Momoge wetland of China. Chinese Geographical Science, 23, 708, 2013.

24. KANAI Y., UETA M., GERMOGENOV N., NAGENDRAN M., MITA N., HIGUCHI H. Migration routes and important resting areas of Siberian cranes (Grus leucogeranus) between northeastern Siberia and China as revealed by satellite tracking. Biological Conservation, 106, 339, 2002.

25. LI X., XU J., QIAN F. Migration Routes of Siberian Crane (Grus leucogeranus) in Spring and Autumn by Satellite Tracking. Wetland Science, 14, 347, 2016.

26. MING J., XIAN-GUO L., LIN-SHU X., LI-JUAN C., SHOUZHENG T. Flood mitigation benefit of wetland soil - A case study in Momoge National Nature Reserve in China. Ecological Economics, 61, 217, 2007.

27. KONG W.-Y., ZHENG Z.-H., WU J.-C., NING Y., WANG Y., HAN X.-D. Foraging habitat selection of Siberian Crane (Grus leucogeranus) during autumn migration period in the Momoge Nature Reserve. Zoological research, 34, 166, 2013.

28. ZRIBI M., LE HÉGARAT S., TACONET O., CIARLETTI V., VIDAL-MADJAR D., BOUSSEMA R. Derivation of wild vegetation cover density in semi-arid regions: ERS2/ SAR evaluation. International Journal of Remote Sensing, 24, 1335, 2003.

29. FERRAZ K., SIQUEIRA M., ALEXANDRINO E., TOMASIO APOLINARIO DA LUZA D., THADEU ZARATE DO COUTOA H. Environmental suitability of a highly fragmented and heterogeneous landscape for forest bird species in south-eastern Brazil. Environmental Conservation, 39, 316, 2012.

30. JORGE M., GALETTI M., RIBEIRO M., FERRAZ K. Mammal defaunation as surrogate of trophic cascades in hotspot. Biological Conservation, 163, 49, 2013.

31. JIANG H., HE C., SHENG L., TANG Z., WEN Y., YAN T., ZOU C. Hydrological modelling for siberian crane Grus Leucogeranus stopover sites in northeastern China. PLoS One, 10, e0122687, 2015.

32. DONG Z., WANG Z., LIU D., LI L., REN C., TANG X., JIA M., LIU C. Assessment of habitat suitability for waterbirds in the West Songnen Plain, China, using remote sensing and GIS. Ecological Engineering, 55, 94, 2013.

33. RÖNKÄ M., TOLVANEN H., LEHIKOINEN E., NUMERS M.V., RAUTKARI M. Breeding habitat preferences of 15 bird species on south-western Finnish archipelago coast: Applicability of digital spatial data archives to habitat assessment. Biological Conservation, 141, 402, 2008.

34. SANDERS M. Effect of changes in water level on numbers of black stilts (Himantopus novaezelandiae) using deltas of Lake Benmore. New Zealand Journal of Zoology, 26, 155, 1999. 
35. CUI Z., ZHANG G., ZHANG L., WU Y. Eco-hydrological Regulations based on Requirement of Grus leucogeranus Habitat A Case of Baihe Lake in Momoge National Nature Reserve. Wetland Science, 16, 509, 2018.

36. LUNARDI V.O., MACEDO R.H., GRANADEIRO J.P., PALMEIRIM J.M. Migratory flows and foraging habitat selection by shorebirds along the northeastern coast of Brazil: The case of Baía de Todos os Santos. Estuarine, Coastal and Shelf Science, 96, 179, 2012.
37. CARDONI D.A., FAVERO M., ISACCH J.P. Recreational activities affecting the habitat use by birds in Pampa's wetlands, Argentina: Implications for waterbird conservation. Biological Conservation, 141, 797, 2008.

38. MCLEOD E.M., GUAY P.-J., TAYSOM A.J., ROBINSON R.W., WESTON M.A. Buses, Cars, Bicycles and Walkers: The Influence of the Type of Human Transport on the Flight Responses of Waterbirds. PLOS ONE, 8, e82008, 2013. 